\title{
Food Safety and Risk Management at Catering Level during the COVID-19
}

\author{
Paul Leung* and Jamie Lo \\ Department of Hospitality Management, Faculty of Management and Hospitality, Hong Kong \\ *Corresponding author: Leung Kin Hang Paul, Department of Hospitality Management, Faculty of Management and \\ Hospitality, Hong Kong
}

\begin{tabular}{|c|c|}
\hline ARTICLE INFO & ABSTRACT \\
\hline Received: July 10, 2020 & \multirow{2}{*}{$\begin{array}{l}\text { Citation: Paul Leung, Jamie Lo. Food Safety and Risk Management at Catering Level } \\
\text { during the COVID-19. Biomed J Sci \& Tech Res 29(1)-2020. BJSTR. MS.ID.004756. }\end{array}$} \\
\hline Published: July 27, 2020 & \\
\hline
\end{tabular}

\section{Introduction}

Food safety has been a major concern from both the policy and business level. In the last couple of decades, studies have been conducted from various dimensions to review the issues. For example, consumers' perceptions on risk and purchase behaviors [1], applications of agrochemicals and additivities [2], food safety and its relationship with climate change [3] and applications of new technologies [4]. There were also research focusing on food safety and foodborne disease such as mad cow disease [4]. Research that focus on the preventive measures in catering floor services, however, are scant. In late 2019, the outbreak of COVID-19 pandemic has alerted both caterers and restauranteurs on the issues of preventive measures for combating the spread of this lethal disease. This short article presented the conceptual framework of a study on the perceived effectiveness of current measures and requirements. The scope includes the concurrent HACCP system and the additional measures that were introduced by the Centre for Food Safety of the HKSAR Government. As of 6th July 2020, there were over 11 million confirm cases and more than 534 thousand deaths reported worldwide. As a special administrative region on the southern coast of China, Hong Kong has effectively contented the damages to 1,269 confirmed cases and only 7 deaths reported. Despite the fact that many local citizens have been condemning the SAR Government's incapability and negligence, the results seem to suggest the contrary. This initial review of the preventive measures is based on a series of in-depth discussion with medical doctors, public health specialists, restauranteurs, and customers. The summarized responses as cited below might not be able to exhaust the opinions of the different stakeholders. They, however, can serve as a steppingstone to further investigation of the subject matters.

\section{HACCP System}

Hazard analysis and critical control points system, or better known as the HACCP system, is a preventive measure using a systematic approach to ensure food safety from biological, chemical, physical, and radiological hazards in the production processes for food items. In certain countries such as the United States of America, HACCP is a mandatory requirement for selected segments of the food industry. Hong Kong, however, only promote the adaptation of HACCP as a good practice. HACCP is based on seven principles. They include analysis of hazards, determination of critical control points, establishment of limits for critical control points, establishment of monitoring procedures for critical points, establishment of corrective actions, establishment of verification procedures, and a record system. The systematic approach, the plan and controlling mechanism are generally good compliance. The logistics, however, can be too tedious and abstract to call for specific actions. For example, the establishment of a record system might not be effective in delivering meaningful results in improvements. The archived reports could be easily becoming a pile of decorations on the shelf rather than an enhancement of knowledge or a trigger for organization's cultural change. Furthermore, these principles only cover part of the catering operations. By and large, the HACCP plans focus on food production and rarely extend their scope to cover food serving and dinner behaviors of the customers. Having said that, HACCP does not delimit itself in food production. It 
can be expanded to cover food serving as well. The variety of operation context and nature of food services, however, would make the establishing of a structural controlling mechanism extremely difficult. During period of crisis, such as the outbreak of transmittable disease, the challenges would be even higher.

\section{COVID-19 Specific Administrative Measures}

Owing the rapid spreading magnitude and the seriousness of the COVID-19 pandemic, the HKSAR Government has implemented a three-prong strategic approach to deal with the crisis and three key strategies to fight the virus. The three approaches include the dissemination of timely information to the publics, preventive measures to combat the virus, and the provision of remedies to ease impacts to the public. The combating strategies included the widened early testing and detection, health quarantine arrangements on inbound travelers, and requirements to reduce gatherings. Amongst these three strategic domains, the requirement to reduce gatherings is directly related to the catering industry. According to the regulation [5], no group gathering may take place in any public place during a specified period. As of the regulation promulgated on March 29, any gatherings of four persons or more will be prohibited [6]. This restriction does not apply to an exempted group gathering specified in Schedule 1; and a group gathering that is permitted by the Chief Secretary for Administration. Person commits an offence may discharge liability by paying a fixed penalty of HK\$2,000. Authorized officers were also empowered to disperse a gathering in a public place.

A second regulation requires restaurants only to serve at a reduced leverage, half of their capacity of customers as of the administrative order on March 28 for 14 days. Each table needs to be separated by at least $1.5 \mathrm{~m}$ and only four people can be seated at a table. Venues such as cinemas, fitness centers and amusement game centers were to close for the same period of 14 days. Temporarily ban alcohol sales in bars and restaurants, and subsequent suspension of operation of such outlets were enforced to enhance social distancing. The preventive measures have been effective in controlling the spreading of the pandemic. There are many criticisms against them. First, the gathering control was said to have devastating effect on the catering industry. The industry has concerns about the lack of consultation before implementation. In response, the SAR Government has provided remedies to relief the impacts on the trade. Given the critical situation and potential threats of the outbreak, decisive action, even at the expenses of certain group's interest might be understandable. Second, the switching to takeaways might not be as effective as planned owing to the lack of responding preventive measures in the food production process. Contamination in the kitchen can be a potential loophole for spreading of the disease.

Besides, the logistics of the material supply chain is another area of threats. There is a possible workplace transmission of
COVID-19 at an imported food warehouse reported in late May $[7,8]$. Although the health Bureau contented that the main mode of transmission is through respiratory droplets, the virus can also be transmitted through contact. That means, there is a possibility that the virus can be transmitted through the supply chain of food materials and the delivery of the food products to the end-users. The current administrative order, as of July 10, restricted the size of dining groups to 8 people but there is no restriction on sharing of dining table with strangers. This not only would enhance the risk of inflection but also make tracing of origins more difficult. HACCP, as a major food safety control mechanism, is designed to prevent/ minimize the risk from the food borne illness. However, COVID-19 is not a kind of food borne illness although it could be transmitted in the restaurant. Therefore, HACCP has its limitations on the prevention of transmittable diseases. HACCP mainly focuses on food production, while COVID-19 transmission could be in both kitchen, dining room or outside the dining areas such as washroom and handrails of staircase.

The concept of HACCP, however, can be capitalized to develop a more advanced system to combat other transmissible disease such as COVID-19. The other preventive measures that the SAR Government is exercising are temporary tactics. They are reactive in nature and do not have the design for sustaining practices. It also suffers the weakness in applicability. A system approach with practical guideline on the prevention of transmitting of disease at catering outlet level, therefore, is deem essential. This short report is an initial review of the current situations in Hong Kong, which constitute part of a bigger project on the administrative measures for combating outbreak of transmittable diseases. As of the submission of this manuscript, the number of confirmed cases in Hong Kong surged again after a period of no reported local transmission. WHO also indicated the needs to investigate how the virus spreads in air. With all these uncertainties and the lack of an effective vaccine, continuous and effective measure in controlling possible transmissions would deem credential.

\section{References}

1. Berg L (2004) Trust in food in the age of mad cow disease: a comparative study of consumers' evaluation of food safety in Belgium. Britain, and Norway. Appetite 42(1): 21-32.

2. Carvalho F (2006) Agriculture, pesticides, food security and food safety. Environmental Science and Policy 9: 685-692.

3. Dong Y, Xu Y, Yong W, Chu X, Wang D (2014) Aptamer and its potential applications for food safety. Critical Reviews in Food Science and Nutrition 54(12): 1548-1561.

4. Duncan T (2011) Applications of nanotechnology in food packaging and food safety: Barrier materials, antimicrobials, and sensors. Journal of Colloid and Interface Science 363(1): 1-24.

5. Government H (2020) Health \& Community. Retrieved from News.gov. hk.

6. Low z, Siu P (2020) Coronavirus: fears over workplace transmission as Hong Kong woman, husband confirmed with Covid-19 and two of her colleague's test positive. Retrieved from South China Morning Post. 
7. Tirado M, Clarke R, Jaykus L, McQuatters Gollop A, Frank J (2010) Climate change and food safety: A review. Food Research International 43(7): 1745-1765.

ISSN: 2574-1241

DOI: $10.26717 /$ BJSTR.2020.29.004756

Paul Leung. Biomed J Sci \& Tech Res

(c) (i) This work is licensed under Creative

Submission Link: https://biomedres.us/submit-manuscript.php
8. Yeung RM, Morris J (2001) Food Safety Risk: Consumer perception and purchase behaviour. British Food Journal 103(3): 170-186.

\begin{tabular}{ll} 
BIOMEDICAL & Assets of Publishing with us \\
RESEARCHES & - Global archiving of articles \\
& - Immediate, unrestricted online access \\
\hline ISSN: $2574-1241$ & - Rigorous Peer Review Process \\
&
\end{tabular}

